\title{
Pulmonary artery pseudoaneurysm embolisation to treat massive haemoptysis due to metastatic oropharyngeal squamous cell carcinoma
}

\author{
Priyan Tantrige, ${ }^{\circledR}$ Edward Johnston, Giorgio Garzillo, Dean Y Huang ${ }^{\odot}$
}

King's College Hospital NHS Foundation Trust, London, UK

\section{Correspondence to}

Dr Priyan Tantrige, priyan.tantrige@gmail.com

Accepted 12 June 2019

\section{DESCRIPTION}

A 57-year-old woman with metastatic oral squamous cell carcinoma presented to the emergency department with massive haemoptysis. Her blood pressure was $96 / 69 \mathrm{~mm} \mathrm{Hg}$ with a heart rate of 65 beats per minute. Laboratory tests showed a mild coagulopathy (INR 1.3) for which vitamin $\mathrm{K}$ and tranexemic acid were administered. CT angiography revealed a metastatic pulmonary cavity, with an adjacent $10 \mathrm{~mm}$ pseudoaneurysm arising from a posterior basal segmental branch of the left pulmonary artery (figure 1). No other pulmonary, bronchial or systemic arterial anomaly was identified. Under general anaesthesia, the left pulmonary artery was selectively catheterised using a steerable $0.035^{\prime}$ guidewire (Storq, Cordis, Baar, Switzerland), a 7F hydrophilic sheath (Ansel, Cook Medical, Indiana, USA) and a 5F multipurpose catheter (Cook Medical, Bloomington, Indiana, USA). Pulmonary artery angiography was performed with arrested respiration and selective pulmonary artery catheterisation carried out with a $130 \mathrm{~cm}$ microcatheter

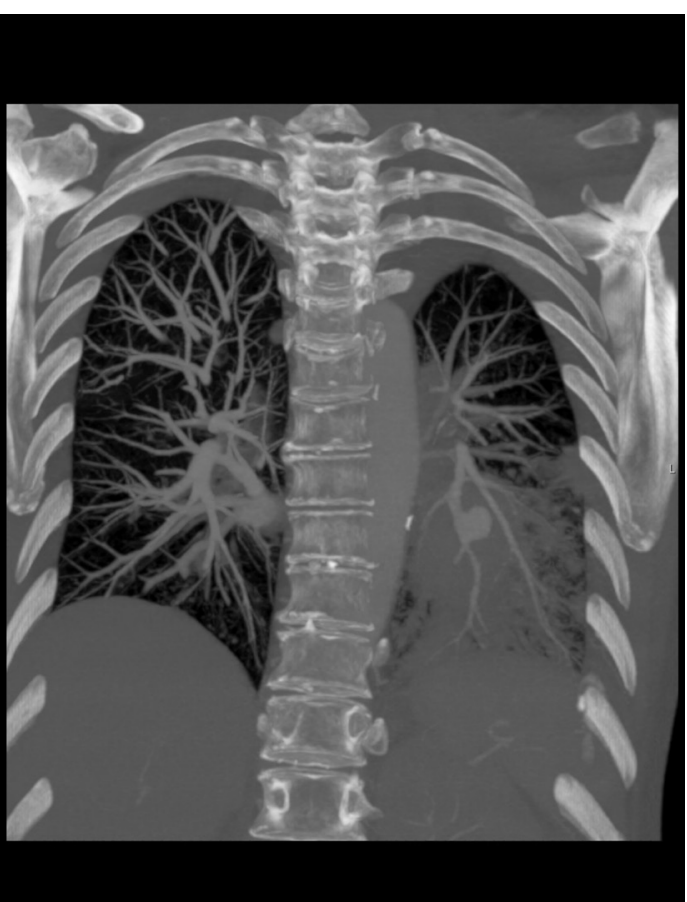

Figure 1 Coronal CT pulmonary angiogram (maximum intensity projection reformat) showing a $10 \mathrm{~mm}$ wide necked pseudoaneurysm originating from the posterior basal segmental branch of the left lower lobe pulmonary artery.
(Progreat, Terumo, Tokyo, Japan). The pulmonary artery proximal and distal to the pseudoaneurysm was embolised with one $7 \times 300 \mathrm{~mm}$ and five $10 \times 500 \mathrm{~mm}$ helix ev3 concerto detachable coils (Medtronic, Minneapolis, Minnesota, USA). The pseudoaneurysm was embolised with a single $7 \times 10 \mathrm{~mm}$ complex helical-18 microcoil and nine $4 \times 7 \mathrm{~mm}$ multiloop-18 microcoils (Boston Scientific, Marlborough, Massachusetts, USA) with satisfactory angiographic result and no filling of the pseudoaneurysm (figure 2). This is also called a sandwich technique. ${ }^{1}$ The patient's haemoptysis resolved, and her vital signs stabilised following the procedure with a short postprocedural stay in intensive care. No further haemoptysis occurred over the next 2 weeks, although she died following a further episode on day 24 postprocedure. Interim investigations with MRI neck and Positron Emission Tomography (PET)-CT demonstrated locoregional recurrence of squamous cell carcinoma and uptake within the pulmonary cavity attributed to metastases. Serial chest radiographs revealed a pleural effusion thought to be infective, in view of an elevated white cell count, which resolved after treatment with piperacillin. No angiographic follow-up was performed. The cause of recurrent massive haemoptysis was not confirmed and a postmortem was not performed.

Massive haemoptysis, defined as blood loss of $300-600 \mathrm{~mL}$ over 24 hours, is a distressing and life-threatening condition. The bronchial arteries are the most common source of haemorrhage, with pulmonary arteries second, accounting for $6 \%-11 \%$ of cases. ${ }^{2} 3$ Pulmonary artery pseudoaneurysms are associated with cavitating infections or malignancy, usually primary lung cancer, and rarely due to metastases. ${ }^{45}$ No difference in pseudoaneurysm morphology or response to treatment has been identified for different types of malignancy.

CT angiography is essential for accurate diagnosis, treatment planning and prognostication and should therefore be performed urgently. Treatment can be pharmacological, bronchoscopic, endovascular or surgical and is often guided by the volume of haemorrhage, the underlying cause, patient's performance status and laboratory results. ${ }^{6}$ Classification on catheter angiography can be used to further determine the endovascular treatment approach. Pseudoaneurysms which are visualised at non-selective (type A) or selective (type B) segmental pulmonary angiography are amenable to endovascular treatment via the pulmonary artery. In 


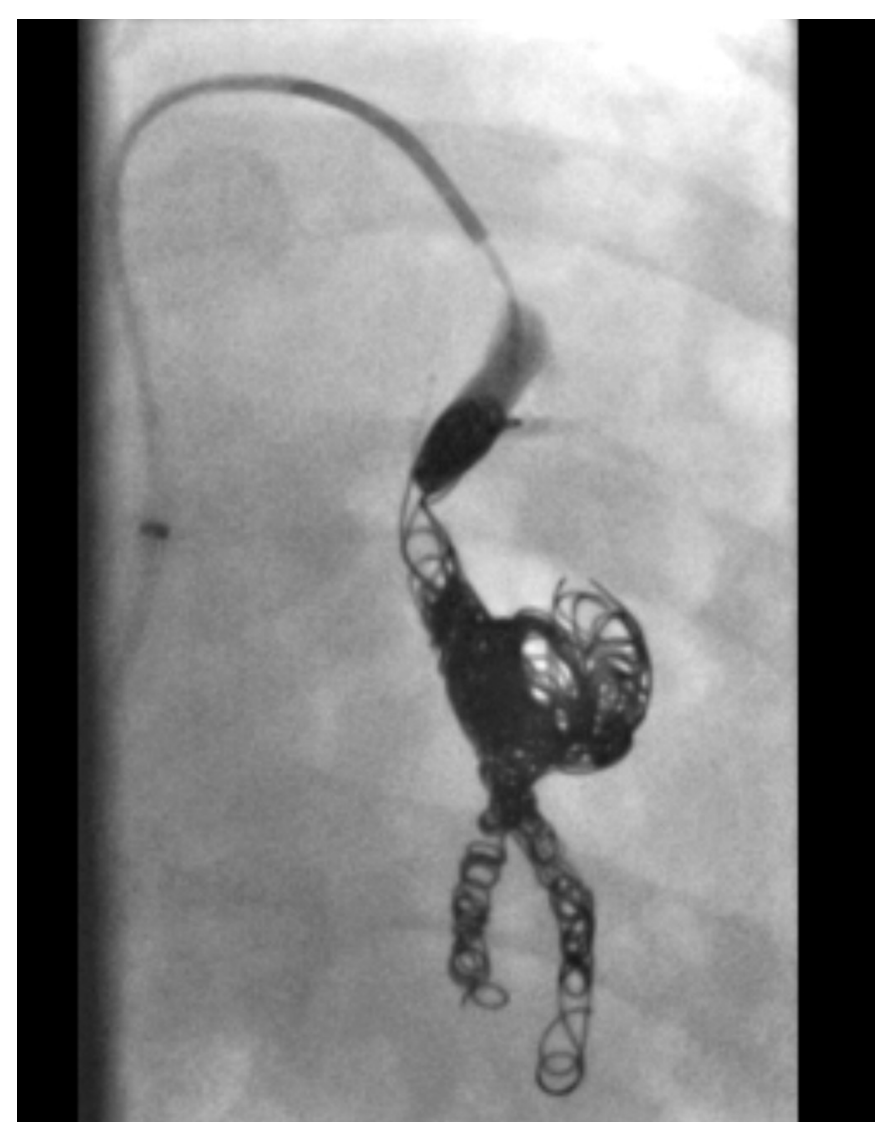

Figure 2 Fluoroscopic image demonstrating contrast at the top of the coil nest suggestive of complete occlusion of the posterior basal segmental pulmonary artery and the pseudoaneurysm with embolisation coils.

contrast, pseudoaneurysms which are only demonstrated with bronchial or other systemic arterial (eg, internal mammary) catheterisation (type C) usually arise from systemic to pulmonary arterial shunts and can be treated by bronchial or systemic arterial embolisation. When a pseudoaneurysm is evident on CT but not on catheter angiography (type D), empirical targeted embolisation based on CT findings may be considered. ${ }^{7}$

Where a massive haemoptysis pathway is in place, the patient may be transferred from the CT scanner to the interventional radiology suite to receive prompt endovascular treatment. Coagulopathy should be corrected in all cases and the airway managed to reduce the risk of aspiration. However we wish to emphasise that while the procedure is safe, the prognosis is still poor even when effective endpoint embolotherapy is carried out. Indeed, survival rates of $67 \%$ and $46 \%$ at 1 and 3 months have been reported in the literature, meaning physicians should be aware of this and the patient should be consented accordingly. ${ }^{8}$ Endovascular embolisation can be used in the emergency setting to allow

\section{Patient's perspective}

I was frightened prior to the procedure and my husband was tearful. We were hugely relieved when I awoke the following day.

\section{Learning points}

- Although massive haemoptysis arises from bronchial or other systemic arteries in most cases, treating physicians should be mindful of the possibility of pulmonary arterial haemorrhage, especially in the context of cavitating pulmonary lesions.

- Early CT angiography should be arranged to make the diagnosis, plan treatment and prognosticate.

- Pulmonary artery pseudoaneurysms can be treated by interventional radiologists using minimally invasive endovascular techniques.

a definitive management strategy to be implemented. Follow-up angiographic imaging should be considered to evaluate embolisation efficacy. The procedure does not preclude surgery should it become necessary, and can alleviate symptoms in the palliative setting.

Contributors PT obtained patient consent and produced the case report. EJ assisted with procedure and reviewed report. GG performed procedure and reviewed report. DYH performed procedure and reviewed report.

Funding The authors have not declared a specific grant for this research from any funding agency in the public, commercial or not-for-profit sectors.

Competing interests None declared.

Patient consent for publication Obtained.

Provenance and peer review Not commissioned; externally peer reviewed.

\section{REFERENCES}

1 Marinček B. Emergency radiology. Berlin: Springer, p, 2007:50.

2 Khalil A, Parrot A, Nedelcu C, et al. Severe hemoptysis of pulmonary arterial origin: signs and role of multidetector row CT angiography. Chest 2008;133:212-9.

3 Sbano H, Mitchell AW, Ind PW, et al. Peripheral pulmonary artery pseudoaneurysms and massive hemoptysis. AJR Am J Roentgenol 2005;184:1253-9.

4 Gomez-Jorge J, Mitchell SE. Embolization of a pulmonary artery pseudoaneurysm due to squamous cell carcinoma of the lung. J Vasc Interv Radiol 1999;10:1127-30.

5 Shum PL, Ngo B, Chen X, et al. Pulmonary artery pseudoaneurysm secondary to metastatic breast cancer. South Asian J Cancer 2018;7:20.

6 American College of Radiology, Haemoptysis: Appropriateness Criteria. 2014. https://www.evidence.nhs.uk/search? om $=(\{\% 22$ ety\%22:[\%22Guidance $\% 22)\}) \& q=$ Hemoptysis\&sp=on (Accessed 17th March 2019).

7 Shin S, Shin TB, Choi H, et al. Peripheral pulmonary arterial pseudoaneurysms: therapeutic implications of endovascular treatment and angiographic classifications. Radiology 2010;256:656-64

8 Marcelin C, Soussan J, Desmots F, et al. Outcomes of Pulmonary Artery Embolization and Stent Graft Placement for the Treatment of Hemoptysis Caused by Lung Tumors. J Vasc Interv Radiol 2018;29:975-80. 
Copyright 2019 BMJ Publishing Group. All rights reserved. For permission to reuse any of this content visit https://www.bmj.com/company/products-services/rights-and-licensing/permissions/

BMJ Case Report Fellows may re-use this article for personal use and teaching without any further permission.

Become a Fellow of BMJ Case Reports today and you can:

- Submit as many cases as you like

- Enjoy fast sympathetic peer review and rapid publication of accepted articles

Access all the published articles

Re-use any of the published material for personal use and teaching without further permission

Customer Service

If you have any further queries about your subscription, please contact our customer services team on +44 (0) 2071111105 or via email at support@bmj.com.

Visit casereports.bmj.com for more articles like this and to become a Fellow 